\title{
Die Grund/duld
}

in îhren

\section{Beziefungen zur per/önlíd)en forderung}

\author{
$\mathfrak{y}_{\text {on }}$ \\ Dr. jur. wo. Woeisbetter \\ Rectsanwalt in Cađjel
}

1922

Muündyen, Berlin, Eeipzíg

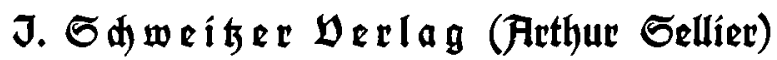


Drư⿱ bon Dr. F. P. Datterer \& Cie., Freifing=Mlündben. 